\title{
Pemberdayaan Program Berkelanjutan Bagi Anak Asuh untuk Menanamkan Nilai-nilai Karakter Cerdas
}

\author{
Fadhilla Yusri ${ }^{1}$, Afrinaldi ${ }^{2}$, Linda Yarni ${ }^{3}$ \\ 1,2,3Institut Agama Islam Negeri (IAIN) Bukittinggi, Indonesia \\ E-mail:fadhillayusri@gmail.com
}

2021 by the authors. Submitted for possible open access publication under the terms and conditions of the Creative Commons Attribution-ShareAlike 4.0 International License-(CC-BY-SA) (https://creativecommons.org/licenses/by-sa/4.0/) DOI : http://dx.doi.org/10.30983/dedikasia.vli1.5122

\section{ARTICLE INFO}

Submit : 02 Januari 2021

Revised : 06 April 2021

Accepted : 30 Juni 2021

\section{Keywords:}

Foster child; values; smart character.

\section{ABSTRACT}

Poverty and neglect are unresolved problems in this country. Based on the results of the study, one of the two cities that have pockets of poverty in West Sumatra is Payakumbuh. Meanwhile, Payakumbuh has the largest export commodity in the livestock sector in West Sumatra. To overcome this, children from underprivileged families, orphans, orphans and abandoned children can be placed in orphanages. At the orphanage, children are expected to have their physical needs met, to develop their personality and to be able to continue their education. However, the reality is that the application of rules and punishments in orphanages makes the children not have intelligent characters as expected. Therefore, the assistance that can be given to assist the application of intelligent character in foster children is by providing group guidance services.

This is an open access article under the CC-BY-SA license

\section{Pendahuluan}

Berdasarkan hasil penelitian, dua kota yang memiliki kantong kemiskinan di daerah Sumatera Barat adalah kota Padang dan kota Payakumbuh (Jayaputra, 2014). Padahal pendapatan daerah kota Payakumbuh tergolong tinggi, apalagi daerah ini memiliki komoditi eksport bidang peternakan terbesar di Provinsi Sumatera Barat. Namun hal itu tidak menjamin semua masyarakatnya dapat hidup sejahtera. Masih banyak masyarakat kota Payakumbuh yang hidup di bawah garis kemiskinan. Keberadaan panti asuhan memberikan angin segar bagi anak-anak dari keluarga miskin, karena mereka memiliki kesempatan untuk melanjutkan pendidikan mereka (Kemensos, 2012); (Ginanjar, 2005). Data terakhir tentang jumlah anak asuh yang tinggal di panti asuhan kota Payakumbuh adalah 61 orang, 30 orang laki-laki dan 31 orang perempuan (BPS, 2014). Hasil penelitian Nanda Sri Anita menyatakan bahwa pola pengasuhan yang umumnya diterapkan pengasuh di panti adalah punitiveness, overprotective dan domination (Anita, 2014). Hal ini didukung oleh hasil penelitian Nina yang mengungkap bahwa anak yang tinggal di panti asuhan memiliki konsep diri yang rendah (Nina, 2014). Penerapan pola asuh yang begitu mengekang dan rendahnya konsep diri anak asuh, akan semakin memperburuk pembentukan karakter cerdas pada diri mereka.

Karakter sebagai sifat pribadi yang relatif stabil pada diri individu yang menjadi landasan bagi penampilan perilaku dalam standar nilai dan norma yang tinggi (Khaidir, 20llb); (Situmorang, 2015). Karakter yaitu sifat kejiwaan, akhlak atau budi pekerti yang menjadi ciri khas seseorang atau sekelompok orang (Majid, 2010); (Supardi, 2011). Kecerdasan adalah kemampuan untuk mengarahkan fikiran atau tindakan, kemampuan untuk mengubah arah tindakan bila tindakan tersebut telah dilaksanakan dan kemampuan untuk mengkritik diri sendiri (Azwar, 2014); (Thomas, 2014). Orang yang cerdas adalah orang yang setiap melakukan tindakan, baik yang berkenaan dengan 
dirinya sendiri maupun bersangkutan dengan orang lain, selalu memposisikan pikiran pada tempatnya (Muslih, 2011); (Suyatno, 2009). Penanaman karakter cerdas diberikan agar generasi muda Indonesia siap menghadapi persaingan global, persaingan yang tetap berlangsung dalam koridor nilai-nilai budaya yang bersifat universal seperti kejujuran, disiplin, toleransi, empati, saling menghormati, tolong-menolong, dan sebagainya (Supardi, 2011); (Hasni, 2021). Komponenkomponen dalam penanaman nilai-nilai karakter antara lain adalah pengetahuan, kesadaran atau kemauan, dan tindakan untuk melaksanakan nilai-nilai tersebut, baik terhadap Tuhan Yang Maha Esa (YME), diri sendiri, sesama, lingkungan, maupun kebangsaan sehingga menjadi manusia insan kamil (Adhim, 2012); (Evitarini, 2019). Lima fokus yang mengandung nilai-nilai karakter-cerdas adalah iman dan takwa, kejujuran, kecerdasan, ketangguhan, dan kepedulian (Khaidir, 201lb); (Sujadi, 2017). Lebih jauh, kandungan kelima fokus nilai-nilai karakter-cerdas dapat dirinci ke dalam butir-butir nilai karakter-cerdas.

Pembentukan karakter dilakukan agar manusia memiliki kesadaran diri. Kecakapan kesadaran diri pada dasarnya merupakan penghayatan diri sebagai hamba Tuhan Yang Maha Esa, sebagai anggota masyarakat dan warga negara, sebagai bagian dari lingkungan (Supardi, 2011); (Alizamar, 2015). Jika cerdas spiritual berfungsi dengan optimal akan sangat efektif mempengaruhi tingkah laku manusia (Manullang, 2007); (Thomas, 2014). Kecerdasan emosional berperan dalam penanaman karakter agar seseorang bersikap: 1) jujur, disiplin, dan tulus pada diri sendiri, membangun kekuatan dan kesadaran diri, mendengarkan suara hati, hormat dan tanggung jawab; 2) memantapkan diri, maju terus, ulet, dan membangun inspirasi secara berkesinambungan; 3) membangun watak dan kewibawaan, meningkatkan potensi, dan mengintegrasi tujuan belajar ke dalam tujuan hidupnya; 4) memanfaatkan peluang dan menciptakan masa depan yang lebih cerah (Mulyasa, 2006); (Gunawan, 2012).

Bimbingan kelompok yang didesain untuk menerapkan karakter cerdas dalam kehidupan dikenal juga dengan Kelompok Pengejawantahan Butir-butir Karakter Cerdas disingkat dengan KPBKC (Sujadi, 2017). KPB-KC adalah kelompok yang berkehendak untuk seia-sekata dalam karaktercerdas, yaitu yang secara nyata menghayati dan mengamalkan nilai-nilai karakter-cerdas dalam wujud perilaku dan kehidupan pada umumnya (Khaidir, 201la); (Sujadi, 2017). Isi kegiatan KPB-KC secara langsung dan dinamis mengarah pada dihayati dan diamalkannya nilai-nilai karakter-cerdas, termasuk nilai-nilai luhur Pancasila di dalamnya, dalam kehidupan nyata, baik kehidupan pribadi, berkeluarga dan berkelompok, bermasyarakat, berbangsa serta bernegara (Khaidir, 201la); (Hasni, 2021). Dalam setiap tahap terdapat langkah-langkah sistematis yang secara kontiniu dilaksanakan untuk mencapai tujuan bimbingan kelompok (Ariani, 2020); (Prayitno, 2004). Topik bahasan yang akan dibicarakan dalam kegiatan bimbingan kelompok dapat berasal langsung dari pimpinan kelompok, atau pimpinan kelompok meminta anggota kelompok untuk menyepakati topik karakter apa yang akan dibahas pada kegiatan (Sukardi, 2008) (Prayitno, 2004).

Analisis penulis berdasarkan pengamatan terhadap tingkah laku anak asuh panti dan wawancara dengan pengurus serta pengasuh panti, masalah yang dihadapi oleh anak asuh panti saat ini adalah besarnya pengaruh lingkungan terhadap tingkah laku mereka. Sudah menjadi pameo bagi masyarakat disekitar panti tentang kenalakan anak panti, ketidaksopanan tingkah laku anak panti, kebiasaan buruk anak panti. Tingginya tingkat sangsi atas pelanggaran yang diberikan oleh pengasuh panti, tanpa dibarengi dengan pemahaman tentang cara bertingkah laku yang tepat dan diharapkan, inilah yang membuat anak panti bertindak tanpa pertimbangan serta tidak memperlihatkan nilainilai karakter cerdas dalam setiap tingkah lakunya.

Untuk menanggulangi hal di atas, sangat perlu dilakukan penanganan cepat yang serius melalui berbagai upaya dan pemberdayaan, solusi yang ditawarkan adalah melalui penguatan psikologis, bimbingan spiritual, serta pelayanan konseling berupa bimbingan kelompok untuk memberikan pemahanan dan menanamkan nilai-nilai karakter cerdas pada anak asuh. Pemberdayaan 
ini bertujuan untuk menghasilkan anak panti asuhan yang memiliki karakter cerdas dan bisa menjadi teladan di lingkungannya.

\section{Metode Penelitian}

Strategi yang akan dilakukan dalam pengabdian ini meliputi, penguatan psikologis untuk memotivasi dirinya agar dapat mengontrol ego dan emosi masing-masing, selain itu untuk menanamkan pemahaman agama kepada anak asuh panti asuhan Aisyiyah kota Payakumbuh. Pihakpihak yang terlibat dalam program dampingan ini adalah, pengurus panti asuhan Aisyiyah kota Payakumbuh, pengasuh panti asuhan Aisyiyah kota Payakumbuh, dan Pemko Payakumbuh dalam hal ini dinsosnaker. Bentuk keterlibatan adalah dalam bentuk kerjasama pemberian bantuan penguatan psikologis, bimbingan spritual, pembentukan karakter cerdas melalui bimbingan kelompok bagi anak asuh panti asuhan Aisyiyah kota Payakumbuh.

Pemberdayaan ini akan dilaksanakan oleh pendamping yang memiliki latar belakang yang sesuai dibidangnya yaitu 1 orang pendamping berlatarbelakang bimbingan konseling, dan 2 orang lagi berlatar belakang psikologi. Untuk membantu kelancaran program di lapangan, pendamping melibatkan pengurus dan pengasuh di panti asuhan Aisyiyah kota Payakumbuh sebanyak 3 orang sebagai mitra kerja. Pendamping juga melibatkan beberapa orang alumni jurusan Bimbingan Konseling IAIN Bukittinggi untuk menjadi konselor muda ketika pelatihan diberikan.

Pelaksanaan pengabdian ini direncanakan selama lima bulan. Kegiatan pengabdian ini dimulai dari pendataan dan pengenalan permasalahan yang dihadapi anak asuh di panti asuhan. Kegiatan pengabdian ini akan diakhiri dengan penyusunan laporan kegiatan pengabdian pada bulan kelima. Peserta dalam pengabdian ini adalah seluruh anak asuh di panti asuhan Aisyiyah kota Payakumbuh putera dan puteri yang berjumlah 61 orang.

\section{Hasil}

Fokus pemberdayaan dalam pengabdian ini dilakukan dengan strategi, (l) penguatan psikologis, (2) bimbingan spiritual, dan (3) layanan bimbingan kelompok untuk menanamkan karakter cerdas anak asuh. Penguatan psikologis dilakukan untuk memotivasi diri anak asuh agar dapat mengontrol pikiran, perasaan dan tingkah laku masing-masing. Bimbingan spiritual diberikan untuk menjaga silaturrahim yang baik dengan anggota panti asuhan, serta meningkatkan pemahaman tentang materi keagamaan lainnya yang bermanfaat bagi kehidupan mereka baik di panti maupun di lingkungan yang lebih luas. Layanan bimbingan kelompok dengan topik tugas untuk membahas berbagai materi yang berhubungan dengan penerapan tingkah laku berkarakter cerdas dalam kehidupan sehari-hari. Pelaksanaan kegiatan pemberdayaan program berkelanjutan bagi anak asuh untuk menanamkan nilai-nilai karakter cerdas dalam kehidupan sehari-hari di panti asuhan aisyiyah kota Payakumbuh dilakukan untuk mencapai harapan agar semua anak asuh dapat menerapkan tingkah laku berkarakter cerdas dimana saja berada.

Penguatan psikologis diarahkan pada kemampuan anak asuh panti asuhan untuk mampu menerima diri dan lingkungannya sebagai upaya awal menanamkan karakter cerdas. Kegiatan penguatan psikologis diawali dengan pemaparan materi pertama tentang kemampuan mengembangkan moral remaja yang sehat dan bermartabat. Selanjutnya materi kedua yang dipaparkan adalah materi tentang kemampuan mengontrol emosi negatif dimanapun berada. Kegiatan diakhiri dengan instrospeksi diri tentang segala kelebihan dan kekurangan yang dimiliki serta keinginan untuk memperbaiki diri ke depannya. Berdasarkan kegiatan penguatan psikologis yang dilakukan dan umpan balik yang diterima dari anak asuh, diketahui bahwa kegiatan penguatan psikologis sangat bermanfaat bagi anak asuh. Setelah mengikuti kegiatan penguatan psikologis anak asuh memahami tentang pentingnya moral dan kemampuan mengontrol emosi bagi remaja agar dapat hidup dengan tenteram dan menjadi remaja yang bersahaja. Anak asuh semakin memahami keadaan 
dirinya terutama berkaitan dengan moral dan pengontrolan emosinya selama ini. Anak asuh berkomitmen untuk memperbaiki moral dan kemampuan mengontrol diri agar menghindari berbagai masalah baik dengan teman di panti, di sekolah maupun di lingkungan lebih luas. Anak asuh juga makin mengenal kelebihan dan kelemahan yang dimiliki sebagai modal dalam mengembangkan diri kedepannya.

Bimbingan spiritual diarahkan pada pengamalan ajaran agama secara komprehensif. Bimbingan spiritual ini diberikan untuk meningkatkan kesadaran diri pada anak asuh panti asuhan. Bimbingan spiritual diawali dengan materi tentang tuntunan sholat dan membaca Al-Qur'an yang benar. Setelah itu, anak asuh menerima materi tentang akhlak terpuji benteng diri untuk tahan uji. Kegiatan bimbingan spiritual diakhiri dengan dilakukannya acara muhasabah untuk menimbulkan kesadaran diri anak asuh sebagai hamba Allah SWT. Berdasarkan kegiatan bimbingan spritual yang dilakukan dan umpan balik yang diterima dari anak asuh, diketahui bahwa kegiatan bimbingan spiritual memberikan banyak perbaikan pada segi ibadah yang dilakukan oleh anak asuh selama ini. Anak asuh menyadari bahwa ibadah merupakan hubungan sakral antara hamba dengan sang khalik, sehingga diperlukan kesadaran dan keikhlasan dalam menjalankannya. Anak asuh berkomitmen akan memperbaiki kualitas sholat dan bacaan al-qur'annya serta beribadah dengan penuh kesadaran bukan keterpaksaan karena aturan panti. Kegiatan muhasabah yang dilakukan di akhir kegiatan bimbingan spiritual makin meningkatkan rasa instrospeksi anak asuh untuk menjadi insan yang lebih baik lagi dalam ibadahnya. Anak asuh menyadari dengan meningkatnya kualitas ibadah maka karakter akan membaik dan tingkah laku menjadi menyenangkan.

Layanan bimbingan kelompok diberikan untuk membantu menanamkan tingkah laku berkarakter cerdas pada diri anak asuh di panti asuhan. Konselor mengabdikan peranan dan jasanya untuk meningkatkan kualitas kehidupan dan menjadikan tahap perkembangan yang mereka jalani menjadi optimal. Kegiatan pertama dilakukan secara klasikal untuk menyampaikan materi tentang karakter cerdas remaja penerus bangsa penegak agama. Setelah itu kegiatan dilanjutkan dengan format kelompok, yaitu melaksanakan layanan bimbingan kelompok untuk menanamkan karakter cerdas bagi anak asuh di panti asuhan aisyiyah kota Payakumbuh. Kegiatan bimbingan kelompok dilakukan dalam empat tahap untuk memnahas secara mendalam dan tuntas topik tentang butirbutir karakter cerdas. Berdasarkan kegiatan bimbingan kelompok yang dilakukan dan umpan balik yang diterima dari anak asuh, diketahui bahwa kegiatan bimbingan kelompok membuka wawasan dan cakrawala berpikir anak asuh terutama tentang pentingnya karakter cerdas dalam kehidupan. Anak asuh menyadari bahwa masih banyak tindakan yang dilakukannya selama ini sangat jauh dari karakter cerdas yang dinahas dalam kegiatan bimbingan kelompok. Selain memberikan pengetahuan dan kesadaran pada anak asuh tentang pentingnya karakter cerdas dalam kehidupan, kegiatan bimbingan kelompok juga mampu memotivasi anak asuh untuk menanamkan dan menerapkan karakter cerdas dalam kehidupannya terutama di lingkungan panti. Aspek kepribadian anak asuh lainnya juga berkembang setelah mengikuti kegiatan bimbingan kelompok diantaranya lebih terbuka, berani mengemukakan pendapat, makin bertoleransi, saling menghargai dan kemampuan berkomunikasi meningkat. Anak asuh sangat bersyukur dapat mengikuti rangkaian kegiatan dalam pengabdian masyarakat yang dilakukan karena memberikan dampak positif bagi diri anak asuh.

\section{Pembahasan}

Pelaksanaan kegiatan pemberdayaan program berkelanjutan bagi anak asuh untuk menanamkan nilai-nilai karakter cerdas dalam kehidupan sehari-hari di panti asuhan aisyiyah kota Payakumbuh dilakukan untuk mencapai harapan agar semua anak asuh dapat menerapkan tingkah laku berkarakter cerdas dimana saja berada. Pendekatan yang digunakan adalah pendekatan pemberdayaan, dengan memberdayakan panti asuhan sebagai lembaga yang mempunyai tanggung jawab untuk memberikan pelayanan kesejahteraan sosial pada anak terlantar dengan memenuhi 
kebutuhan fisik, mental dan sosial kepada anak asuh sehingga mereka memperoleh kesempatan bagi pengembangan kepribadiannya dan pengembangan konsep diri yang positif pada diri mereka (Usman, 2004); (Poerwanto, 2008).

Fokus pertama adalah aspek psikologi diarahkan pada kemampuan anak asuh panti asuhan untuk mampu menerima diri dan lingkungannya sebagai upaya awal menanamkan karakter cerdas. Kemampuan ini bisa berupa menerima kekurangan fisik, kekurangan ekonomi dan sosial diri maupun teman-temannya (Prayitno; Amti, 2002); (Suyatno, 2009). Kemudian setelah mampu menerima diri sendiri, orang lain dan lingkungan diharapkan dapat menyesuaikan diri, mampu saling bekerja sama, toleransi, suka menolong, bersama-sama menjaga fasilitas yang disediakan, saling mengingatkan, suka memberi dan saling memaafkan. Konselor perlu membantu klien untuk menyesuaikan diri dengan baik terhadap kondisi kehidupannya dan dapat mencapai tujuan pribadinya dengan baik (Gladding, 2012); (Rahmadani, R and Neviyarni, 2021). Fokusnya adalah mengubah atau menghapuskan tingkah laku mal-adaptif yang ditunjukkan klien, sambil membantunya mendapatkan cara bertindak yang sehat dan konstruktif.

Fokus kedua dalam kegiatan pemberdayaan ini adalah aspek keagamaan diarahkan pada pengamalan ajaran agama secara komprehensif. Karena ajaran islam memiliki dampak bagi ketenangan jiwa dan kesehatan mental dalam kehidupan kalau dilakukan secara komprehensif (Majid, 2010); (Usman, 2004). Materi yang diberikan adalah materi keagamaan secara dasar, seperti tuntunan sholat dan mengaji yang benar. Hal ini diberikan karena masih banyak anak asuh di panti asuhan yang belum memiliki kemampuan dan kesadaran untuk beribadah sesuai dengan syari'at islam (Majid, 2010); (Ginanjar, 2005). Materi keagamaan ini diberikan untuk meningkatkan kesadaran diri pada anak asuh panti asuhan. Kecakapan kesadaran diri pada dasarnya merupakan penghayatan diri sebagai hamba Tuhan YangMaha Esa, sebagai anggota masyarakat dan warga negara, sebagai bagian dari lingkungan, serta menyadari dan mensyukuri kelebihan dan kekurangan yang dimiliki, sekaligus menjadikannya sebagai modal untuk meningkatkan diri sebagai individu yang bermanfaat bagi diri sendiri maupun lingkungannya (Supardi, 2011); (Mariana, 2016).

Fokus ketiga dalam pemberdayaan ini adalah pelayanan konseling yang diberikan untuk membantu tertanamkannya tingkah laku berkarakter cerdas pada diri anak asuh di panti asuhan. Menurut Prayitno warga masyarakat dilingkungan perusahaan, industri, kantor-kantor, organisasi pemuda, bahkan di lembaga pemasyarakatan, rumah jompo, panti asuhan, rumah sakit dan sebagainya tidak terhindar dari kemungkinan menghadapi masalah (Prayitno; Amti, 2002); (Ariani, 2020). Dalam kegiatan kelompok ini, akan dimunculkan topik-topik bahasan tentang karakter cerdas yang akan dibahas secara bersama oleh anggota kelompok dan dipimpin oleh pimpinan kelompok. Pada akhir kegiatan bimbingan kelompok, masing-masing anggota kelompok dimintai komitmennya tentang penerapan tingkah laku berkarakter cerdas dalam kehidupan sehari-hari. Pelaksanaan bimbingan kelompok untuk membahas topik tentang karakter cerdas dinilai efektif untuk menanamkan tingkah laku berkarakter cerdas pada anak asuh di panti asuhan (Situmorang, 2015); (Kustini, 2016). Pada akhirnya diharapkan mereka dapat merubah tingkah laku yang tidak baik menjadi tingkah laku yang berkarakter cerdas dalam kehidupan. Penilaian dan pandangan masyarakatpun akan berubah kepada mereka, bahkan ini juga dapat membuka peluang bagi mereka untuk sukses di masyarakat nantinya setelah mereka keluar dari panti asuhan.

Berdasarkan pemberdayaan yang telah diberikan pada anak asuh di panti asuhan aisyiyah kota Payakumbuh berupa penguatan psikologis, bimbingan spiritual dan bimbingan kelompok untuk menanamkan karakter cerdas, semuanya sangat memberikan manfaat berarti bagi anak asuh, pembina dan pengurus panti asuhan. Kegiatan pemberdayaan ini perlu dilakukan secara kontiniu dan terprogram agar apa yang sudah diterima oleh anak asuh dapat terus dikembangkan dan terjadi perbaikan secara berkelanjutan pada diri anak asuh. Pengelolaan yang baik pada kegiatan ini juga sangat diperlukan agar kegiatan lebih terarah dan memberikan kemanfaatan bagi anak asuh. Kegiatan 
pemberdayaan ini baru dilakukan pada satu panti asuhan di kota Payakumbuh. Melihat keefektifan dan kebermanfaatan pemberdayaan yang telah dilakukan baik untuk anak asuh, pembina, maupun pengurus panti asuhan maka barangkali pemberdayaan ini dapat dilakukan pada panti asuhan lain yang juga membutuhkan. Pelaksanaan kegiatan pemberdayaan dapat disesuaikan dengan kondisi anak auh, pembina, pengurus dan kondisi panti asuhan itu sendiri agar tidak mengurangi makna dan manfaatnya.

\section{Kesimpulan}

Program berkelanjutan bagi anak asuh untuk menanamkan nilai-nilai karakter cerdas dalam kehidupan sehari-hari di panti asuhan aisyiyah kota Payakumbuh yang dilakukan ini adalah menindaklanjuti dari kegiatan Praktek Pengalaman Lapangan Bimbingan dan Konseling di Luar Sekolah (PPLBKLS) yang pernah dilakukan oleh mahasiswa jurusan Bimbingan Konseling IAIN Bukittinggi. Masalah yang dihadapi oleh anak asuh di panti asuhan aisyiyah kota Payakumbuh adalah mereka kembali kehilangan panutan dan orang yang akan mengingatkan serta menuntun mereka untuk menerapkan tingkah laku berkarakter cerdas.

Fokus kegiatan dalam pemberdayaan ini adalah (l) penguatan psikologi, maksudnya penguatan ini diberikan karena anak asuh belum mampu mengontrol emosi dan ego sehingga menyebabkan mereka belum bisa menyikapi berbagai konflik yang terjadi dengan kepala yang dingin, (2) bimbingan spiritual yang diberikan kepada anak asuh di panti asuhan adalah tuntunan beribadah yang baik dalam islam, dan (3) pelayanan konseling yang diberikan berupa layanan bimbingan kelompok yang dilakukan untuk dapat memberikan pemahaman kepada anak asuh tentang nilainilai karakter cerdas.

Berdasarkan hasil penilaian yang telah diberikan kepada semua peserta kegiatan, kemudian tim melakukan analisis terhadap hasil penilaian. Dari hasil analisis tersebut, dapat disimpulkan bahwa peserta mendapatkan pengetahuan yang baru dari kegiatan yang mereka ikuti. Kemudian mereka merasa senang telah mendapatkan berbagai materi dari narasumber. Mereka mengatakan akan berusaha untuk merubah tingkah laku mereka yang salah menjadi tingklah laku yang berkarakter cerdas. Terakhir mereka juga menyatakan akan melakukannya dengan sungguh-sungguh.

\section{Kepustakaan}

Adhim, F. (2012). Hubungan Pendidikan Karakter Terhadap Kecerdasan Emosional Pada Mahasiswa Fakultas Ekonomi Universitas Kanjuruhan Malang. Jurnal Inspirasi Pendidikan Ukama, 1(2).

Alizamar, A. (2015). Pengembangan Karakter-Cerdas Mahasiswa melalui Infusi dalam Pembelajaran. International Counseling Seminar.

Anita, N. (2014). Pola Asuh Pengasuh Panti Asuhan Aisyiyah.

Ariani, F. (2020). Peningkatan Pemahaman Siswa tentang Nilai-Nilai Karakter-Cerdas dengan Menggunakan Media Film. Menara Ilmu, https://doi.org/https://doi.org/10.31869/mi.vl4i2.2247

Azwar, S. (2014). Pengantar Psikologi Inteligensi. Pustaka Pelajar.

BPS. (2014). Data Kependudukan.

Evitarini, A. (2019). Pengembangan Karakter Cerdas melalui Bimbingan dan Konseling pada Anak Usia Dini di TK Islam Sarana Bhakti. Psikodidatika, 4(2). https://doi.org/https://doi.org/10.32663/psikodidaktika.v4i2.984

Ginanjar, A. (2005). Rahasia Sukses Membangun Kecerdasan Emosi dan spiritual: ES2. Arga.

Gladding, S. (2012). Konseling Profesi yang Menyeluruh. Indeks. 
Gunawan, H. (2012). Pendidikan Karakter Konsep dan Implementasi. Alfabeta.

Hasni, H. et all. (2021). Urgensi Pendidikan Kewarganegaraan dalam Social Studies sebagai Pembentukan Karakter Cerdas bagi Generasi Muda pada Era Global. Supremasi, 16(1). https://doi.org/https://doi.org/10.26858/supremasi.vl6il.20501

Jayaputra, A. (2014). Pemetaan Kemiskinan dan Strategi Pengentasannya Berbasis Institusi Lokal dan Berkelanjutan di Era Otonomi Daerah di Provinsi Sumatera Barat.

Kemensos, K. (2012). Standar Nasional Pengasuhan Untuk Lembaga Kesejahteraan Sosial Anak.

Khaidir, P. \&. (201la). Kelompok Pengejawantahan Butir-butir Karakter Cerdas. UNP Press.

Khaidir, P. \&. (20llb). Model Pendidikan Karakter Cerdas. UNP Press.

Kustini, S. (2016). Pengembangan Karakter Cerdas Melalui Pembelajaran Bahasa Inggris. INTEKNA: Informasi Teknik Dan NIaga, 16(2).

Majid, A. (2010). Pedidikan karakter dalam perspektif Islam. Insan Cita Utama.

Manullang, B. (2007). Landasan Ilmiah Ilmu Pendidikan. UNIMED Press.

Mariana, D. (2016). Membentuk Karakter Cerdas melalui Bimbingan dan Konseling Perkembangan untuk Menghadapi MEA. Jurnal Bimbingan Konseling Indonesia, 1(1), 18-22.

Mulyasa, E. (2006). Standar Kompetensi dan Sertifikasi Guru. Remaja Rosdakarya.

Muslih, M. (2011). Pendidikan Karakter Menjawab Tantangan Krisis Multidimensional. Bumi Aksara.

Nina, N. (2014). Pengaruh Layanan Bimbingan Kelompok terhadap Konsep Diri Anak Asuh di Panti Asuhan Aisyiyah.

Poerwanto, H. (2008). Kebudayaan dan Lingkungan Dalam Perspektif Antropologi. Pustaka Pelajar.

Prayitno; Amti, E. (2002). Dasar-dasar Bimbingan dan Konseling. Rineka Cipta.

Prayitno, P. (2004). Layanan Bimbingan Kelompok dan Konseling Kelompok. UNP Press.

Rahmadani, R and Neviyarni, N. (2021). Pendidikan Karakter Cerdas. Pendidikan Tambusai, 5(1). https://doi.org/https://doi.org/10.31004/jptam.v5il.979

Situmorang, M. (2015). Pengaruh Layanan Bimbingan Kelompok dengan Menerapkan Pembelajaran Karakter Cerdas Kelompok terhadap Kecerdasan Sosial Siswa Kelas VIII SMP Negeri IOnan Ganjang Kab.Humbang Hasundutan. Psikologi Konseling, 7(2). https://doi.org/https://doi.org/10.24114/konseling.v7i2.5115

Sujadi, E. (2017). Penerapan Pendidikan Karakter Cerdas Format Kelompok untuk Meningkatkan Nilai Kejujuran Mahasiswa Bimbingan Konseling Islam (BKI) Institut Agama Islam Negeri (Iain) Kerinci. Tarbawi: Jurnal Ilmu Pendidikan, 13(1).

Sukardi, D. (2008). Proses Bimbingan dan Konseling di Sekolah. Rineka Cipta.

Supardi, B. (2011). Membangun Karakter Bangsa Berbasis Spiritual. Yogyakarta. Prosiding Seminar Nasional MIPA.

Suyatno, S. (2009). Urgensi Pendidikan Karakter. Depdiknas.

Thomas, L. (2014). Educating For Character (Mendidik untuk membentuk karakter). Bumi Aksara.

Usman, S. (2004). Pembangunan dan Pemberdayaan Masyarakat. Pustaka Pelajar. 